\title{
Disruption in Indian Cellular Telecom Market: Critical Success Factors
}

\author{
Abdhesh Kumar Singh, Pramod Pathak, Saumya Singh
}

\begin{abstract}
Cellular telephony is today acting as fulcrum in driving the socio-economicdevelopment of a country. The objective of this paper is to delve deeper into the Indian telecom market's opportunities and challenges in the fast changing technology and cost ecosystemandspecifically factoring in the critical success factors of an aggressive new telecom operator Reliance Jio. This also encapsulates what government has been doing to take the telecom forward to meet its visions. This encompasses the data inputs from online secondary sources along with voice of customers with the help of primary data (data collected during Dec 2018-Feb 2019) basis a questionnaire based field survey and interview of industry experts.
\end{abstract}

Keywords : Telecom Marketing, Rural Telecom, Disruption, Competition, Jio, India.

\section{INTRODUCTION}

A populous country like India tends to invite the monetisation of technological proliferations happening across the world. It invites economic opportunities. More than two third of Indian population stays in rural areasand because of this scale, there is a need to make rural economy more sustainable when we all know that population has been migrating from rural areas for better earning options and resultantly if we look at quality of life in urban areas it is becoming a stress on urban infrastructure and life.

Disruptive entry by a telecom operator recently and its success in terms of customer market share and profit generation generates curiosity amongst all the affected machinery (like incumbents, government, academia et al). From government's angle, telecom disruption can improve consumers reach, betterquality and price discovery amidst healthy technology led competition.

In the telecom landscape, the gap in teledensity of India vis-à-vis the world scenario throws up food for analysis and action. The table named Table 1-World Scenario below not only reflects the gap of India's teledensity vs the world but also exposes the stark difference that of developed as well as developing nations. There has been a growing digital gap between the rural \& urban connectivity with urban areas getting most of the $3 \mathrm{G} \& 4 \mathrm{G}$ roll-out due to higher profitability \& smartphone ecosystem. Indian telecom subscriber base has surpassed one billion and is the world's second largest market in this industry with more than 521 million rural subscribers (TRAI, Mar 2018).

\section{Teledensity:}

a)

Table1 : World Scenario

\begin{tabular}{|c|c|c|c|c|}
\hline Year & World & $\begin{array}{c}\text { Developed } \\
\text { Countries }\end{array}$ & $\begin{array}{c}\text { India } \\
\text { Developing } \\
\text { Countries }\end{array}$ & $\begin{array}{c}\text { (Source: } \\
\text { TRAI-Marc } \\
\text { h Quarter of } \\
\text { every year) }\end{array}$ \\
\hline $\mathbf{2 0 1 2}$ & 88.5 & 115.7 & 82.7 & 76.0 \\
\hline $\mathbf{2 0 1 3}$ & 93.1 & 118.2 & 87.8 & 70.9 \\
\hline $\mathbf{2 0 1 4}$ & 96.7 & 122.0 & 91.4 & 72.9 \\
\hline $\mathbf{2 0 1 5}$ & 97.4 & 125.2 & 91.7 & 77.3 \\
\hline $\mathbf{2 0 1 6}$ & 100.7 & 126.8 & 95.5 & 81.4 \\
\hline $\mathbf{2 0 1 7}$ & 103.6 & 127.0 & 99.0 & 91.1 \\
\hline $\mathbf{2 0 1 8}$ & 107.0 & 128.0 & 102.8 & 91.1 \\
\hline
\end{tabular}

Source: ITU World Telecommunications/ICT Indicator

Database

We can see how it has moved within India, in rural as well as urban areas in the table named Table 2- India Scenario Total wireless teledensity /Urban Teledensity/Rural Teledensitybelow.

b)

Table 2- India Scenario - Total wireless teledensity /Urban Teledensity/Rural Teledensity

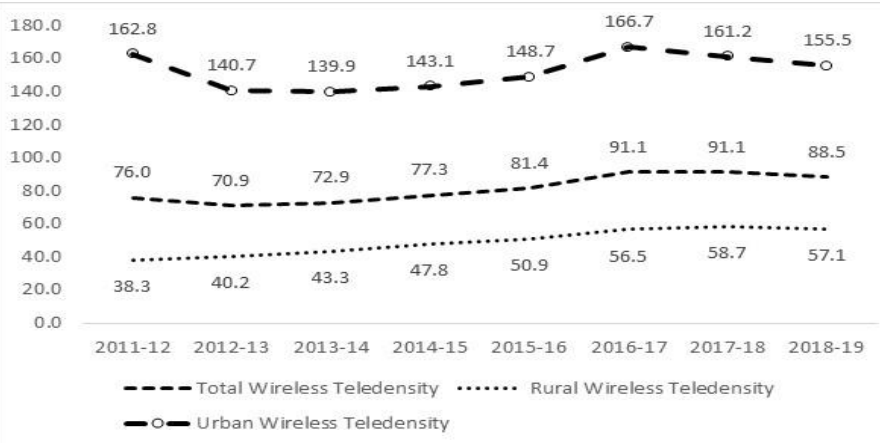

(Source: TRAI Quarterly Performance Indicator Reports Teledensity nos as of Mar Qtr end for each year)

Wireless Subscribers base : Now within India, where is the gap in teledensity! In around 377million urban population there are more than 662 million connections, whereas, in around 833 million rural population of India (mospi.gov.in), the mobile connections count is just above 521millionand this is a great opportunity (TRAI, Mar 2018). 
Table 3- Rural \& Urban Wireless base

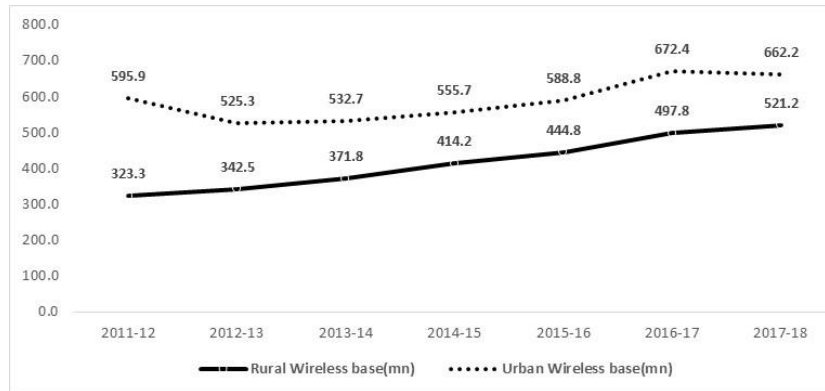

(Source: TRAI Quarterly Performance Indicator Reports nos as of Mar Qtr end for each year)

State wise Rural Teledensity : The tables Table 2 and Table 3 abovepresented how the rural cellular mobile base and teledensity is faring at national level. The below representation picturises the state wise rural teledensity stands. Bihar, Madhya Pradesh, Uttar Pradesh etc are comparatively at a lower level.

\section{Table 4 - Rural Wireless Teledensity}

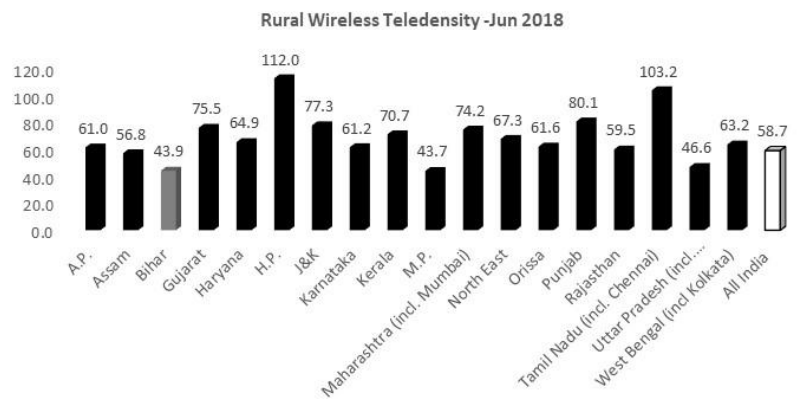

(Source: TRAI Apr-Jun 2018 Quarterly Performance Indicator Report)

We have studied the factors or challenges that were tackled by Reliance Jio and helped it in making quick inroads and will also try to sense the voice of customers from rural areas specifically. So, the paper would deal with the various related literatures, important movements in Indian telecom sector, deciphering the customer impacting factors and conclusions.

\section{LITERATURE REVIEW}

Studies related to telephony and acceptability of telephony in ruralareas had been carried out across European, African and Asian countries. Overall challenges in rural areas like logistical challenges due to their remoteness (Katrina Kosec, Leonard Wantchekon, 2018), importance of considering various group specific needs and reservations while marketing of mobile services (Gupta, R., \& Jain, K., 2015) were highlighted.

Ruhita Gupta, Karuna Jain have also mentioned a study by Wei and Zhang (2008) which deliberated on mobile adoption in rural China considering the factors like cost, mass-media use, inter-personal communication and the perceived need for mobile telephony.

Gupta and Jain, 2014 had identified five new factors that influence the adoption of mobile telephony in rural India and extended TAM by incorporating these factors. In addition to the usual factors PU, PEOU, PI, SI, mass media (MM), mobility (MOB), and cost of service (CS) — Gupta and Jain (2014) identified cost of handset $(\mathrm{CH})$, perceived health hazard (PHH), lack of ease of service accessibility (LEOSA), lack of transparency of mobile service offerings (LOTSA) and lack of service quality (LSQ) as factors affecting IA (intention to adopt) for mobile telephony in rural India. They had recommended for innovative tariff plans (like family-type packages and offering benefit to users who introduce other to the network) and the availability of cheaper handsets with simple functions specifically designed for older people to enhance adoption. However, these techniques had been tried by telco operators earlier in some or other form and had not succeeded in any significant way. A literature by Ioanna D. Constantiou (Telematics and Informatics, Copenhagen Business School, Denmark, 2009) (though not directly on rural population) had mentioned thatLu et al. (2005) extended the TAM for wireless internet adoption by incorporating concepts such as social influences and personal traits. Similarly, Wu and Wang (2005) had also enriched TAM with constructs regarding perceived risk, cost, and compatibility, while Yang (2005) had added individual characteristics, such as innovativeness, past adoption decisions, and knowledge about technology, as external antecedents of TAM constructs. Further, Kim et al (2007) developed the value-based adoption model including benefits as well as sacrifices in the adoption process of mobile internet, whereas Massey et al. (2005) identified technology readiness and wireless web sites interface usability as key factors influencing the uptake of mobile commerce and services. This indicative, though non-exhaustive, listing of research efforts underpins how the domain of mobile data services adoption and diffusion has acquired an important position within the research agenda of telecommunications industry.

The research on external socio-economic factors affecting consumer behaviour towards mobile data services identified some main areas such as the acceptance of new technological solutions (e.g. GPRS enabled ones) (Hung et al., 2003), the pricing schemes and the brands (Turnbull and Leek, 2000) as well as the mobile advertising ( $\mathrm{Oh}$ and $\mathrm{Xu}, 2003$ ). Though over the years after these observations, technology has not remained limited to simple GPRS.

Constantiou, 2009 had stated the challenge faced by vendors to induce the individual to sample the service (Anckar and D'Incau, 2002; Sarker and Wells, 2003), in a marketing driven approach, these models predicted that once the service was sampled, the individual would eventually adopt it.

\section{Status of Telecom Sector - India}

India is divided into 22 telecom licensed areas (or circles). There are now eight licensed telecom operators (on records) in India now and most of the private mobile network footprint (PAN India) is primarily dominated by three operators named as Airtel, Vodafone-Idea \& Reliance Jio. 


\begin{tabular}{|c|l|l|}
\hline $\begin{array}{c}\text { Sr. } \\
\text { No } \\
.\end{array}$ & $\begin{array}{l}\text { Service } \\
\text { Provider }\end{array}$ & Licensed Service Areas \\
\hline 1 & Bharti Airtel Ltd & All India \\
\hline 2 & $\begin{array}{l}\text { Vodafone Idea } \\
\text { Ltd }\end{array}$ & All India \\
\hline 3 & $\begin{array}{l}\text { Reliance } \\
\text { JioInfocom Ltd }\end{array}$ & All India \\
\hline 4 & $\begin{array}{l}\text { Reliance } \\
\text { Communications }\end{array}$ & All India (except Assam \& NE) \\
\hline 5 & BSNL & All India (except Delhi \& Mumbai) \\
\hline 6 & $\begin{array}{l}\text { Tata } \\
\text { Teleservices }\end{array}$ & All India except Assam, NE \& J\&K \\
\hline 7 & MTNL & Delhi \& Mumbai \\
\hline 8 & $\begin{array}{l}\text { Reliance } \\
\text { Telecom Ltd }\end{array}$ & $\begin{array}{l}\text { Kolkata, MP, WB, HP, Bihar, } \\
\text { Odisha, Assam \& NE }\end{array}$ \\
\hline
\end{tabular}

(Source: TRAI Indicators Dec 2018)

The Indian Telecommunications network with 1183.68 million wireless connections (as on 28 February 2019, Telecomwatch) is the second largest in the world after China. This rapid growth has been possible by various proactive and positive decisions of the Government and contribution of both by the public and the private sectors. The brisk progresses in the telecom sector have been assisted by fair policies of the Government that provides easy market access for telecom equipment and an open minded guidingstructure for offering telecom services to the Indian consumers at affordable prices. Presently, all the telecom services are open for private participation.

Off late the proliferation of internet coupled with affordable handsets have enabled a plethora of value added services which we can call New-age VAS like Live Streaming, online gaming, Digital Pooja, Location based services etc.

We are now in a fast $4 \mathrm{G}$ era and looking towards $5 \mathrm{G}$. Technically, the wireless signalling for telecom services have moved from $1 \mathrm{G}$ (Analog radio signalling technology) to $2 \mathrm{G}$, $3 \mathrm{G}, 4 \mathrm{G}$ (the newer versions being digital signal transmission technology and are faster).

India is classified into approximately 630 thousand villages, which can be sorted in different parameters such as literacy levels, income levels, penetration, distance etc. The main reason why the companies are focusing on rural market and developing effective strategies is to tap the market potential and can be identified as follows: Increasing purchasing power, developing infrastructure, however, there are challenges like low standard of living with diverse socio-economic backwardness, traditional outlook (hence, resistance to change), marketing mix (the urban products cannot be forced onto rural population). Various studies (e.g., fishermen in the Indian state of Kerala and grain producers in Niger) have shown that increased mobile service penetration in rural areas could have tremendous socio-economic benefits for the rural population (cisco.com, 2013).

\section{PRIVATE TELCOS'STRATEGY}

Telecom has been a capital intensive industry as

a)

An operator would need most of the population to be covered, that too including railways and highways and providing for network decongestion

Need to match up with ongoing technological advancements, participation in spectrum auctions

\section{To do $R \& D$ and innovation so that it gains} competitive edge

In a paper named "Rural Telecom in India: Marketing Issues and Experiences from Other Countries" by Rajesh K Aithal and Arunabha Mokhopadhyay, 2002 had highlighted the reasons for some success of rural telecom in countries like Bangladesh, Philippines, Chile and African areas during 2001-2007. Primarily, favourable results were contributed by effective use of microfinance network, upgraded GSM technologies, subsidy, affordable recharge denominations, minimising regulations, Govt leadership, faster availability of mobile coverage, low price handsets etc.

\section{RESEARCH METHOD}

A two prong method was undertaken:

1) Primary research in two rural heavy states of India to corroborate existing problems and identifying new challenge (if any)

2) Secondary research through online available articles and Experts' views

A survey was targeted for at around 500 respondents, however, with a questionnaire segregated into 9 categories with each category having multiple options to be ticked upon (a mix of rankings and 5 scale ratings), it was an absolute difficulty to convince these many respondents in rural areas of Bihar and West Bengal states of India. A total of 276 people responded meaningfully.This part of research lays importance on illustrating and interpretation of outcome based on data analysis aiming to transfer raw data into significant information. Secondly and most importantly industry experts' views were taken because in addition to data analysis from primary survey, they are the only person who have feel of the actual matter (challenges, opportunities and resources) going on in the telecom companies - be it operational or at strategy level. Most of these would not be available or easily available in public domain.

\section{RESEARCH FINDINGS}

Primary Research: The sample that responded during the survey during Dec 2018-Feb 2019 were spread across occupation and income categories as tabulated below: 
Disruption in Indian Cellular Telecom Market: Critical Success Factors

Table 5 - Family Income Spread of the sample

\begin{tabular}{|c|c|c|c|c|c|}
\hline \multirow{2}{*}{ Occupation } & \multicolumn{5}{|c|}{ Family Monthly Income Buckets } \\
\hline & $<20000$ INR & 20000-30000 INR & $30000-40000$ INR & $>40000$ INR & Total \\
\hline Agriculture & $56 \%$ & $37 \%$ & $7 \%$ & $0 \%$ & $100 \%$ \\
\hline Businessman & $17 \%$ & $38 \%$ & $14 \%$ & $31 \%$ & $100 \%$ \\
\hline Professional & $45 \%$ & $26 \%$ & $16 \%$ & $13 \%$ & $100 \%$ \\
\hline Salaried Person & $17 \%$ & $41 \%$ & $12 \%$ & $31 \%$ & $100 \%$ \\
\hline Student & $67 \%$ & $24 \%$ & $2 \%$ & $7 \%$ & $100 \%$ \\
\hline Others (didn't Disclose) & $75 \%$ & $25 \%$ & & & $100 \%$ \\
\hline Total & $32 \%$ & $35 \%$ & $11 \%$ & $22 \%$ & $100 \%$ \\
\hline
\end{tabular}

Almost one third of the respondents (32\%) had comparatively low monthly family income (<INR20,000). This spread of income in Table T5 signifies that a good chunk of the sample population on both ends of the table. The top four outputs of primary survey has been plotted on the three sections below:

a) Customer Satisfaction: The ranking spread of operators as per rural customers' perceived satisfaction reflected that Jio was the top most operator at $51 \%$ person putting it in Rank 1 (ref Table $\mathrm{T} 6$ below).

Table 6 - Perceived Ranking of Telecom Operators by respondents

Perceived Ranking of Operators \% Spread

\begin{tabular}{|l|c|c|c|c|c|}
\hline Major Operators & Rank 1 & Rank 2 & Rank 3 & Rank 4 & Rank 5 \\
\hline Jio & $\mathbf{5 1 \%}$ & $18 \%$ & $10 \%$ & $6 \%$ & $15 \%$ \\
\hline Airtel & $19 \%$ & $\mathbf{4 1} \%$ & $24 \%$ & $10 \%$ & $5 \%$ \\
\hline Vodafone & $10 \%$ & $14 \%$ & $\mathbf{3 1 \%}$ & $27 \%$ & $18 \%$ \\
\hline Idea & $4 \%$ & $16 \%$ & $29 \%$ & $\mathbf{3 7 \%}$ & $13 \%$ \\
\hline BSNL & $10 \%$ & $8 \%$ & $8 \%$ & $26 \%$ & $49 \%$ \\
\hline
\end{tabular}

b) Customers' expectation: The frequency distribution spread has been captured in the table Table 7 below and it reflects that the two different geographies (Bihar sample and West Bengal sample) voice for different Top 2 factors as desired marketing strategies to be adopted within telecom operators' plan for them to be adopted in the mass.

In the state of Bihar, people voiced for Low Price and High Quality Service that an operator should ensure to pull customers, whereas, most of the respondent of West Bengal vouched for High Quality Service and Credit facility as factors that should be part of strategy of Telecom operators.

Table 7 - What customers prefer Frequency Spread of Focussed Marketing Strategy as per Customer Voice

\begin{tabular}{|l|c|c|c|c|c|c|c|}
\hline Rural State & Low price & $\begin{array}{c}\text { High Quality } \\
\text { service }\end{array}$ & $\begin{array}{c}\text { After sales } \\
\text { service }\end{array}$ & Credit purchase & $\begin{array}{c}\text { Door to Door } \\
\text { Sales }\end{array}$ & $\begin{array}{c}\text { No hidden } \\
\text { terms \& } \\
\text { conditions }\end{array}$ & $\begin{array}{c}\text { Add more entertainment } \\
\text { apps (like YouTube, Music, } \\
\text { Games etc) }\end{array}$ \\
\hline Bihar & $21 \%$ & $22 \%$ & $12 \%$ & $10 \%$ & $10 \%$ & $18 \%$ & $6 \%$ \\
\hline West Bengal & $15 \%$ & $34 \%$ & $19 \%$ & $21 \%$ & $5 \%$ & $6 \%$ & $1 \%$ \\
\hline
\end{tabular}

c) The Ad factors that are more acceptable was tried to be gauged, wherein, respondents of Bihar state were seemingly influenced by Slogan/Jingle and Promotional Offers; respondents from West Bengal voiced that they were influenced by Promotional offer and the Appeal (i.e. how a telco approached the customers)

Table 8 - Influencing factors in Advertisements

\begin{tabular}{|l|c|c|c|c|c|c|}
\hline \multicolumn{2}{|l|}{ Advertisement Influence about the Brands (factors) } \\
\hline Rural State & Celebrity & $\begin{array}{c}\text { Slogan / } \\
\text { Jingle / Song }\end{array}$ & Theme & $\begin{array}{c}\text { Sales } \\
\text { Promotional } \\
\text { Offer }\end{array}$ & Appeal & $\begin{array}{c}\text { Not } \\
\text { Influenced }\end{array}$ \\
\hline Bihar & $21 \%$ & $22 \%$ & $15 \%$ & $26 \%$ & $8 \%$ & $8 \%$ \\
\hline West Bengal & $13 \%$ & $16 \%$ & $13 \%$ & $25 \%$ & $30 \%$ & $3 \%$ \\
\hline
\end{tabular}

d) We tried to have a spread of the influencing source through which customers come to know about the brand or operators' services. The table below reflects the spread (percentage calculated through count of instances each 'source' featured in the responses) 
Table 9 - Source of knowledge about the operators and its services

Source of Brand Awareness - Frequency Distribution

\begin{tabular}{|l|c|c|c|c|c|c|c|c|}
\hline Rural States & TV & Retailers & Online & $\begin{array}{c}\text { Friends or } \\
\text { Relatives }\end{array}$ & $\begin{array}{c}\text { Sales } \\
\text { Persons }\end{array}$ & Radio & $\begin{array}{c}\text { While } \\
\text { Shopping }\end{array}$ & Newspaper \\
\hline Bihar & $39 \%$ & $12 \%$ & $16 \%$ & $22 \%$ & $5 \%$ & $3 \%$ & $2 \%$ & $1 \%$ \\
\hline West Bengal & $28 \%$ & $8 \%$ & $28 \%$ & $13 \%$ & $9 \%$ & $0 \%$ & $3 \%$ & $13 \%$ \\
\hline
\end{tabular}

Though TV has been a common source of information in many customers related researches, hereapart from TV, both the states (Bihar \& West Bengal) are reflecting that "Friends or Relatives" also have and can have a substantial influence in bringing in the potential customers to the brand and or telco operator.

\section{Secondary Research:}

Industry experts during their interviews said that the world of telecom in India witnessed a huge change with the advent of cellular telephony in late 90's and moved leaps and bounds since then. Till 2007, the cellular telephony space was dominated by Reliance Communications, Airtel, Idea, Loop Telecom (in limited service areas) and Tata (CDMA). Then it was joined by Aircel, Vodafone, MTS, Telenor, Videocon in the bandwagon and the latest has been Reliance Jio which brought in a paradigm shift in the industry and services. The Jio led price war seemingly compelled to takeover of operators like Telenor and part of TATA Teleservices by Airtel and off late the merger of Vodafone and Idea as well. The experts were asked critical questions like despite incumbents having the capability why they didn't take the market in a big way (the way Jio played) to subtle yet vital points like innovative manpower sourcing and utilisation and distribution differentiators. Rather than putting up what happened to incumbents the experts interview focus was on how it happened to them (the dent to incumbents). It would not be fair to compare disruptive attempts in a market like India to those of like in Europe (Free Mobile, Vodafone et al) due to its size and demographic, socio-economic diversity. The manpower gap and Impact of 'scale':

Reliance Jio was having more than $1,50,000$ people were on the rolls in 2018 (business today.in, Apr 2018) and Large operator like Airtel was struggling to keep 20,000 employees due to impending cost pressure (business-standard.com, Nov 2017). Vodafone Idea was looking to limit it's headcount to around 15,000 (economictimes.indiatimes.com, Sep 2018). So Reliance Jio clearly had strategically used more hand to gain market shares quickly than the incumbents would have ever thought of. Not only Jio used huge scale in manpower to get an edge but also its distribution channel and points of presence was at massive level.

The stores are known as Jio Points and last mile presence in $5000+$ towns which were planned to be used as last mile connection (economictimes.indiatimes.com, Dec 2018). So apart from just a traditional retailer channel it made inroads into villages in a disruptive way which if competition wishes to match may take a substantial time.

It used rural entrepreneurship and build-up of trust in rural areas to take on the market. Local people were given preference in building relationship with Jio that connected the common cord.In products front, Jio just didn't depend on curtaining prices and making voice free and data affordable (below Rs10 per GB against Rs 250 per GB by incumbents) but also created a $4 \mathrm{G}$ handset ecosystem with the launch of affordable smart phone (Jio Phone) with inbuilt features of Jio TV, video calling are attracting the mass like never-before as these are on the finger tips wherein people need to click icons. There were already affordable phones below Rs2000 price point, still Jio Phone could garner more than 1/3rd handset market share by Mar 2018 (business today.in, Apr 2018)

Disruptions by telecom operators earlier were limited to pricing or few promotional offers. Jio has created an entire end to end consumer and enterprise market impactingecosystem through multiplier investments into fibres, manpower and physical infrastructures.

Clearly there was impact of this disruption by Jio on sectoral investments, employment, mergers \& acquisitions apart from just prices.It has grabbed a mammoth customer market share of 26.4\% (Telecomwatch, Mar 2019) in just over two and half years' time frame.

\section{CONCLUSION AND FUTURE RESEARCH}

\section{From customers'voice:}

a. Field Survey results on the Customer Satisfaction (question was "Please rank which mobile services provider you are satisfied with) reflect that Jio was clear leader in their minds while thinking of satisfaction.

b. On the customers expectation from telecom operators (the question in the survey questionnaire was "According to you what would be the best marketing strategy that you can suggest to cellular service providers"); apart from the common low price and service quality, credit facility and after sales service also seemed as important factors that should be part of core strategy of Telecom operators. Here comes the correlation wherein Jio had tried to address this with innovative and futuristically planned village level presence of Jio Point stores (more than 5000 nos pan India, https://economictimes.indiatimes.com, Dec13, 2018)) which is certainly a competitive advantage. This point becomes important when one thinks of scale in distribution and reach despite incremental investment and risk which incumbents shirked from barging into.

c. In response to the question "In case you are influenced by advertisement, please tick which among the following factors influenced you (Celebrity, Slogan / Jingle / Song, Theme,Sales Promotional Offer,Appeal, Not Influenced): Apart from sales promotion related offers, people seem to be influenced by slogans and appeal. This becomes important in how telecomoperators approached the customers, e.g. Jio intended to change the way people live. 


\section{Disruption in Indian Cellular Telecom Market: Critical Success Factors}

d. Apart from normal source of information, a substantial number of times people mentioned "Friends or Relatives" also impact adoption which indicates that the "trust" factor works there in villages and had been proven by the way Jio had run the rural entrepreneurship approach which had encompassed local people in talukas and panchayats to create affinity and adoption.

\section{From Experts' voice:}

There are many subtleties that is not available there in open domain of knowledge. Veteran within the industry are able to understand what factor is working and what not and to what extent. Focussed group discussions had been conducted with plethora of experts in marketing, sales and distribution, technology and human resources planners to understand the success factors from each angles.

Experts have been interacted with to come to concluding factors.

They say, any disruption in a market like India asks for huge investment outlay given the geographies and demographics here.

When asked about key differentiators of Jio against other operators' disruptive attempts earlier, experts mentioned the following out of their on-ground and hands-on experience:

a) Scale $-\mathrm{Be}$ it in terms of physical footprint to address service or employee counts to keep a connect and association of trust by taking help of local people, it was on a huge scale which was not limited to fragmented areas. Bulk of the investment outlay during the initial phase helps the marketingof services e.g. ample number of telecom towers at the beginning itself (rather than phased coverage of population as many other Indian operators did) leaves little margin of error to convince customers to go with it for long term.

b) Substantially higher channel commission $(>6 \%)$ : So that it becomes difficult to divert the channel (retailers, distributors) in any tactics by competition who had been with lower commission structures over years and foremost helps the channel RoI (Return on Investment)

c) Technology - It was not just limited to simple low-priced voice, it was $4 \mathrm{G}$ VoLTe with affordable data, telecom towers connected with fibre, affordable high-tech phone (jio Phone) All these above by Jio meant that it created a complete eco-system and that too with similar level of debts as the incumbents are having at the moment. Apart from the above it was the mindset of the people at the top in the company to give big in a big way.

Further to say, fibre is the solution to meet the new age technology demand and surge in data consumption. Fiberisation faces many challenges and one of the major being getting a RoW (Right of Way). The challenges of getting RoW to be sorted out under the ambit of proposed body (National Digital Grid) to lay fibre cables and common use of fibre resources that can rationalise the cost factor of telcos to carry the huge upcoming data demand. What the incumbents could not do was thinking of new technology in a wide scale and a 360 degree manner.

\section{REFERENCES}

1. Aithal Rajesh K and Mokhopadhyay Arunabha, 2002, Rural Telecom in India: Marketing Issues and Experiences from Other Countries" cisco.com, 2013

2. Constantiou Ioanna D. (Telematics and Informatics, Copenhagen Business School, Denmark, 2009)

3. Gupta,R.,\&Jain,K.Adoption behaviour ofruralIndiaformobiletelephony:Amultigroupstudy. Telecommunications Policy (2015), http://dot.gov.in/national-telecom-policy-1994 (accessed, $6 / 6 / 2019)$

4. https://economictimes.indiatimes.com/industry/services/retail/reliance-reta il-may-use-5k-jio-points-for-e-comm-connect/articleshow/67069324.cm $s$ ?from $=\mathrm{mdr}$

5. https://main.trai.gov.in/sites/default/files/A_TwentyYear_Odyssey_1997 _2017.pdf

6. https://www.business-standard.com/article/companies/airtel-staff-count-sh rinks-by-1-805-in-a-year-100-000-telecom-jobs-at-risk-117103101163 -1.html

7. https://www.businesstoday.in/sectors/telecom/mukesh-ambani-reliance-jio -plans-hire-80000-employees-this-financial-year/story/275742.html

8. https://www.cisco.com/c/en/us/solutions/collateral/service-provider/vni-se rvice-adoption-forecast/Cisco_BhartiAirtel_CS.html

9. https://www.ibef.org/industry/telecommunications.aspx

10. Katrina Kosec, Leonard Wantchekon, 2018

11. McKinsey Report on "Global flows in Digital Age: How Trade, Finance People and Data connect the World Economy ", P-122, Apr, 2014 (https://qtxasset.com/cfoinnovation/field/field_p_files/white_paper/WP_ McKinsey\%20Global\%20Institute_Global\%20Flows\%20in\%20a\%20 Digital\%20Age.pdf)

12. mospi.gov.in, India in figures, 2018, p6, p12 of 37).

13. Randolph A Jaramillo (2002)

14. Telecomwatch.in (Feb 2019, Mar 2019)

15. TRAI

(https://main.trai.gov.in/release-publication/reports/performance-indicat ors-reports)-The Indian Telecom Services Performance Indicators, January-March 2012 - 2019, Dec 2018, Jun 2018)

16. usof.gov.in

17. YEBOAH ASIAMAH, Responsibility (CSR) And Ethics in the Telecommunication Industry in Ghana: A case Study of MTN Ghana 